\title{
RELEVANSI KURIKULUM DAN WUJUD KONGKRET TUJUAN PEMBELAJARAN BAHASA ARAB
}

\author{
Novita Rahmi \\ Institut Agama Islam Negeri Metro \\ E-mail:novitarahmi85@yahoo.co.id
}

\begin{abstract}
Learning is a conscious effort to achieve specific goals. Meanwhile, the curriculum is a tool to achieve the desired educational goals. Manifestations of the curriculum in a learning activity consists of several components that work together to achieve educational goals. Besides the curriculum should serve as guidance in organizing educational activities carried out in schools. The curriculum also regulate matters relating to the type of program, for the organization, strategy implementation, the responsible, infrastructure, and others. Thus, the curriculum is closely linked to the learning objectives. Likewise with Arabic learning, curriculum developed useful as possible to realize the goal of learning Arabic. All the elements related to the curriculum as an educational tool, children of students, the situation of education and learning activities work together to achieve the desired goal. The curriculum is a means to achieve educational goals.
\end{abstract}

Key words: Curriculum, Educational Goals.

\begin{abstract}
Abstrak
Belajar adalah upaya sadar untuk mencapai tujuan tertentu. Sementara itu, kurikulum adalah alat untuk mencapai tujuan pendidikan. Manifestasi kurikulum dalam kegiatan belajar terdiri dari beberapa komponen yang bekerja sama untuk mencapai tujuan
\end{abstract}


pendidikan, diantaranya: tujuan pembelajaran, materi pelajaran, metode dan media, serta evaluasi. Selain itu kurikulum harus menjadi panduan dalam mengorganisir kegiatan pendidikan yang dilakukan di sekolah. Kurikulum juga mengatur hal-hal yang berkaitan dengan jenis program, organisasi, implementasi strategi, tanggung jawab, infrastruktur, dan lain-lain. Dengan demikian, kurikulum terkait erat dengan tujuan pembelajaran. Begitu juga dengan pembelajaran bahasa Arab, kurikulum berkembang semaksimal mungkin untuk mewujudkan tujuan belajar bahasa Arab yang ideal. Bahasa Arab yang terdiri dari 3 unsur bahasa (bunyi, kosakata, kaidah tata bahasa) dan 4 kompetensi bahasa (menyimak, berbicara, membaca, dan menulis) harus terangkum di dalam kurikulum bahasa Arab sehingga peserta didik mampu menguasai semua tujuan pelajaran bahasa Arab yang telah ditetapkan. Semua unsur yang berkaitan dengan kurikulum sebagai alat edukasi dan situasi kegiatan belajar mengajar bekerja sama untuk mencapai tujuan yang diinginkan. Oleh karena itu dapat dikatakan bahwa kurikulum merupakan sarana untuk mencapai tujuan pendidikan.

Kata Kunci: Kurikulum, Tujuan Pembelajaran

\section{A. Pendahuluan}

Pada dasarnya, tujuan pembelajaran, materi pelajaran, metode dan media, serta evaluasi merupakan komponen utama di dalam suatu kurikulum. Komponen ini saling berkaitan antara satu dengan yang lain, tujuan berkaitan erat dengan bahan pelajaran, proses belajar mengajar dan penilaian. Bahkan antar komponen tidak hanya berkaitan dengan satu arah saja tetapi dua arah yang menunjukkan hubungan timbal balik. Setiap aspek tujuan mempunyai tingkat kesulitan yang berbedabeda, aspek afektif yang menekankan karakter anak seperti membentuk manusia yang jujur, bertanggung jawab, bertaqwa kepada Allah SWT, bijaksana, sopan, dan lain-lain tentu akan lebih sulit mewujudkannya dibandingkan dengan mencapai tujuan pada aspek pengetahuan atau 
kognitif. Dengan catatan bahwa pengetahuan yang diberikan benar-benar mendukung tercapainya tujuan pendidikan.

Setiap bahan pelajaran dengan tujuan tersendiri memerlukan proses belajar mengajar yang khas pula. Penggunaan metode yang variatif dalam pengajaran perlu diaplikasikan. Adapun evaluasi sebagai komponen kurikulum yang terakhir juga mempunyai peranan yang penting. Alat penilaian yang digunakan harus mampu menggambarkan hasil yang dicapai. Adakalanya alat tersebut tidak relevan karena tidak mempunyai tujuan esensial dan sering dipaksakan, seperti menilai siswa dalam jumlah besar dengan waktu yang terbatas pula. Pada umumnya anak belajar mata pelajaran yang akan diujikan karenalulus ujian sangat penting untuk masa depan mereka. Demikian juga dengan guru yang cenderung mengajarkan materi yang diharapkan keluar dalam ujian. Karena banyaknya yang lulus dengan angka baik merupakan alat penilaian masyarakat terhadap mutu sekolah. Dengan sendirinya guru akan memilih proses belajar yang sesuai demi terwujudnya tujuan pendidikan yang diinginkan.

Berdasarkan urgensi keterkaitan antara komponen kurikulum tersebut, maka perencanaan dan penyusunan masing-masing komponen perlu diperhatikan dan diteliti dengan baik. Ditambah lagi masingmasing komponen sudah memiliki peran yang sangat besar pula dalam mewujudkan kurikulum yang ideal. Begitu juga dengan pendidikan bahasa Arab, tujuan, materi, metode, media dan evaluasi harus disusun sebaik dan sematang mungkin, guna menjadikan pembelajaran berjalan lancar dan terarah. Jika kita fokus pada tujuan pembelajaran bahasa Arab, secara general dapat dilihat dari sudut pandang strategis filosofis dan bersifat kurikuler. Uraian mengenai Keterkaitan antara kurikulum dan tujuan pembelajaran bahasa Arab akan dijabarkan pada pembahasa berikut ini. 


\section{B. Pembahasan}

\section{Kurikulum}

Kurikulum berasal dari bahasa Yunani, pada awalnya digunakan dalam bidang olah raga, yaitu kata "currere" yang berarti jarak tempuh lari. Kemudian istilah kurikulum mengalami pergeseran arti dalam dunia pendidikan. Kurikulum diartikan sebagai sejumlah mata pelajaran atau ilmu pengetahuan yang ditempuh atau dikuasai untuk mencapai suatu tingkat tertentu atau ijazah. Di samping itu, kurikulum juga diartikan sebagai suatu rencana yang sengaja dirancang untuk mencapai sejumlah tujuan pendidikan. ${ }^{1}$

David Pratt mendefenisikan kurikulum secara sederhana, yaitu seperangkat organisasi pendidikan formal atau pusat-pusat pelatihan yang mempunyai katakteristik sebagai berikut:

a. Kurikulum adalah suatu rencana atau intention yang tidak hanya berupa perencanaan (mental) saja, tetapi pada umumnya diwujudkan dalam bentuk tulisan;

b. Kurikulum bukanlah kegiatan, melainkan perencanaan atau rancangan kegiatan;

c. Kurikulum berisi berbagai macam hal seperti masalah yang harus dikembangkan dalam diri siswa, evaluasi untuk menafsirkan hasil belajar, bahan dan peralatan yang dipergunakan, kualitas guru yang dituntut, dan sebagainya;

d. Kurikulum melibatkan maksud atau tujuan pendidikan formal, maka ia sengaja mempromosikan belajar, bukan tanpa rencana atau kegiatan tanpa belajar;

e. Sebagai perangkat organisasi pendidikan, kurikulum menyatukan berbagai komponen seperti tujuan, isi, sistem

1 M. Ahmad, Dkk, Pengembangan Kurikulum, (Bandung: Pustaka Setia, 1998), h. 9. 
penilaian dalam satu kesatuan yang tak terpisahkan, dengan kata lain kurikulum adalah sebuah sistem. ${ }^{2}$

Dari beberapa pengertian kurikulum di atas, penulis menyimpulkan bahwa kurikulum merupakan seperangkat rencana pengajaran yang didesain untuk mencapai tujuan pembelajaran.

Pada hakikatnya kurikulum sangat komplek karena banyak faktor yang terlibat di dalamnya. Oleh karena itu, setiap kurikulum harus didasarkan pada asas-asas berikut ini: ${ }^{3}$

a. Asas filosofis, pada hakikatnya menentukan tujuan pendidikan.

b. Asas sosiologis, memberikan dasar untuk menentukan hal-hal yang akan dipelajari sesuai dengan kebutuhan masyarakat, kebudayaan, dan perkembangan ilmu teknologi.

c. Asas organisasitoris, memberikan dasar-dasar dalam bentyk bagaimana bahan pelajaran itu disusun, bagaimana luas dan urutannya.

d. Asas psikologis, memberikan prinsip-prinsip tentang perkembangan anak dalam berbagai aspek serta cara belajar agar bahan yang disediakan dapat dicerna dan dikuasai oleh anak sesuai dengan taraf perkembangannya.

Asas-asas di atas cukup kompleks dan mengandung hal-hal yang saling bertentangan. Falsafah yang berbeda-beda, religius atau sekuler, demokratis atau otoriter, mempunyai cara tersendiri dalam mewujudkan tujuan yang diinginkan. Asas-asas ini hendaknya mewarnai seluruh komponen kurikulum yang terdiri dari tujuan,

2 Burhan Nurgiantoro, Dasar-Dasar Pengembangan Kurukulum Sekolah, (Yogyakarta: BPFE, 1988), h. 6.

3 M. Ahmad, Dkk, Pengembangan Kurikulumt..., h. 15. 
bahan pelajaran (materi pelajaran), proses belajar mengajar (strategi, metode, teknik, media, sarana prasarana), dan penilaian (evaluasi, tes).

\section{Fungsi dan Peran Kurikulum}

Setiap lembaga pendidikan, baik formal maupun informal dalam penyelenggaraan kegiatan pendidikan berlandaskan kurikulum yang meliputi rancangan kurikulum; berupa proses buku kurikulum suatu lembaga, pelaksanaan kurikulum; berupa proses pendidikan dalam mencapai tujuan, dan evaluasi kurikulum; berupa penilaian dan penelitian hasil pendidikan. Pada dasarnya kurikulum berfungsi: ${ }^{4}$

\section{a. Fungsi bagi sekolah yang bersangkutan}

Bagi sekolah, kurikulum berfungsi sebagai alat untuk mencapai tujuan pendidikan yang diinginkan. Manifestasi kurikulum dalam kegiatan belajar mengajar di sekolah berupa program pengajaran yang terdiri dari beberapa komponen yang bekerja sama untuk mencapai tujuan pendidikan. Tujuan pendidikan yang berjenjang disusun secara berjenjang mulai dari pendidikan yang bersifat nasional sampai yang bersifat instruksional.

Selain itu kurikulum bagi sekolah berfungsi sebagai pedoman dalam mengatur kegiatan pendidikan yang dilaksanakan di sekolah. Di samping itu kurikulum juga mengatur hal-hal yang berhubungan dengan jenis program, cara penyelenggaraan, strategi pelaksanaan, penanggung jawab, sarana prasarana, dan lain-lain.

\section{b. Fungsi bagi sekolah berikutnya}

Kurikulum berfungsi sebagai pengontrol atau pemelihara keseimbangan proses pendidikan. Dengan mengetahui kurikulum sekolah pada tingkat tertentu, maka kurikulum pada tingkat sekolah

${ }^{4}$ Ibid, h. 97. 
berikutnya dapat menyesuaikan. Peyesuaian itu dimaksudkan untuk tidak mengulangi penyampaian bahan pengajaran dan untuk menjaga kesinambungan bahan pengajaran.

\section{c. Fungsi bagi masyarakat}

Pada umumnya sekolah dipersiapkan untuk terjun di masyarakat atau bekerja sesuai dengan keterampilan profesi yang dimilikinya. Oleh karena itu kurikulum harus mencerminkan kebutuhan masyarakat. Untuk itu pihak sekolah dan pihak luar perlu mengadakan kerja sama dalam hal pembenahan kurikulum yang diharapkan.

Dalam rangka menerapkan, mengimplementasikan, dan mengelola kurikulum, kurikulum memiliki peran sebagai berikut: ${ }^{5}$

\section{a. Peranan Konservatif}

Kebudayaan ada sejak adanya manusia dan terus berkembang secara turun temurun. Suatu generasi menerima kebudayaan dari generasi sebelumnya yang berisikan kewajiban dan tindakantindakan yang diterima dan ditolak atau tindakan yang dilarang dan diizinkan. Semua kebudayaan yang telah membudidaya tersebut harus ditransmisikan kepada anak didik selaku generasi penerus. Oleh karena itu semuanya itu menjadi tang jawab kurikulum dalam menafsirkan dan mewariskan nilai-nilai budaya yang mengandung makna dalam membina perilaku anak didik. Sekolah sebagai lembaga sosilan sangat berperan dalam mempengaruhi perilaku anak sesuai dengan nilai-nilai sosial yang ada dalam masyarakat. Jadi kurikulum bertugas menyimpan dan mewariskan nilai-nilai budaya.

5 ibid, h. 109. 


\section{b. Peranan Kreatif}

Kurikulum harus mampu melakukan kegiatan-kegiatan kreatif dan konstruktif dengan menyusun pengalaman belajaryang bersumber dari masyarakat, berupa mata pelajaran yang diajarkan kepada anak didik. Upaya ini dapat membantu mengembangkan semua potensi yang ada pada anak didik sehingga kurikulum itu sendiri dapat mendorong dan dan mempengaruhi anak didik untuk mengembangkan daya kreatifnya.

\section{c. Peranan Kritis dan evaluatif}

Sekolah sebagai pusat budaya sosial tidak hanya berperan mewariskan norma-norma budaya masyarakat, tetapi juga berperan dalam memilih unsur-unsur kebudayaan. Selanjutnya, klasifikasi yang siap untuk dievaluasikan dijadikn bahan-bahan pengalaman belajar dengan didesain menjadi mata pelajaran. Karena itu kurikulum sangat berperan aktif dalam kontrol sosial dan menekankan unsur berpikir kritis di mana nilai-nilai sosial tidak sesuai dengan perkembangan teknologi disisihkan dan nilai-nilai yang sesuai ditata untuk diorganisasikan menjadi pengalaman belajar yang mampu mengembangkan sikap kritis anak ke arah pembentukan pribadi yang terintegrasi dengan kehidupan nyata di masyarakat.

\section{Tujuan Pembelajaran Bahasa Arab}

Pembelajaran bahasa Arab berkaitan dengan ilmu bahasa secara teori dan praktis (aplikasi bahasa). Secara teori, bahasa Arab mencakup dua pembahasa besar, yaitu unsur bahasa dan kompetensi bahasa. Unsur bahasa berkaitan dengan bunyi bahasa (fonetik), kosa kata dan makna kata (semantik), dan tata bahasa (gramatika sintaksis). Sedangkan kompetensi bahasa berkaitan dengan 
kompetensi menyimak, berbicara, membaca, dan menulis. Secara praktis (aplikasi bahasa) membahasa tentang perkembangan ilmu bahasa sesuai dengan kebutuhan masyarakat. Di sinilah kita temukan penggabungan beberapa ilmu atau multidisipliner seperti linguistiksosiologi disebut dengan sosiolinguistik, linguistik-psikologi disebut dengan psikolinguistik, dll.

Dalam mencapai tujuan pendidikan bahasa Arab seluruh kegiatan yang dibutuhkan anak untuk menggunakan bahasa atau berkomunikasi perlu diperhatikan. Karena bahasa tersebut akan dapat dikuasai jika selalu dipakai dalam kehidupan sehari-hari. Bagaimana suatu bahasa akan terus digunakan anak dalam kehidupan sehari-hari? Ini berkaitan dengan fungsi bahasa itu sendiri. Bahasa sebagai materi yang diajarkan harus mempunyai fungsi dibawah ini : ${ }^{6}$

a. Fungsi Manfaat, bahasa tersebut digunakan untuk memenuhi kebutuhan hidup, seperti kebutuhan sandang, pangan, dan papan.

b. Fungsi Aturan, bahasa itu digunakan untuk mengungkapakan aturan atau mengarahkan prilaku orang lain.

c. Fungsi Interaktif, bahasa yang diajarkan tersebut digunakan sebagai alat komunikasi manusia, bertukar fikiran dan ide seseorang dengan yang lain.

d. Fungsi Kepentingan Pribadi, bahasa tersebut digunakan seseorang untuk mengungkapkan perasaan dan ide fikirannya.

e. Fungsi Eksplorasi, bahasa yang diajarkan tersebut digunakan untuk mengungkapkan dan menafsirkan penyebab

${ }_{6}$ Rusydi Ahmad Thu'aimah, Manahuju Tadris al Lughah al 'Arabiyah bi at Ta'lim al Asasi, (Kairo: Dar al Fikri al 'Arabiy, 1998), h. 46. 
terjadinya suatu fenomena dan keinginan seseorang untuk menelitinya.

f. Fungsi Imaginatif, bahasa tersebut digunakan untuk mengungkapkan imajinasi dan daya khayal seseorang walaupun hal tersebut tidak sesuai dengan kenyataan/fakta.

g. Fungsi Penjelas, bahasa tersebut digunakan dalam mewakili ide gagasan dan pengetahuan serta menyampaikannya kepada orang lain.

Setiap kurikulum harus memuat komponen-komponen yang berkualitas. Sama halnya dengan tujuan pembelajaran. Kurikulum harus memuat tujuan pembelajaran yang disusun dengan baik, yang mencakup tujuan bersifat institusional, kurikuler per mata pelajaran sampai kepada tujuan masing-masing langkah item-item pengajaran, baik tujuan umum ataupun tujuan khusus.

\section{a. Tujuan umum}

\section{1). Strategical Objectives}

a). Untuk membina kebudayaan Indonesia

Indonesia termasuk negara yang sebagian besarnya memeluk agama Islam. Hal ini memungkinkan bahasa Arab menjadi bahasa kedua setelah bahasa Indonesia. Sampai saat ini bahasa Arab menduduki tempat pertama sebagai bahasa Asing yang dipelajari pada lembaga-lembaga pendidikan Islam mulai dari tingkat dasar, menengah, dan tinggi. Hal ini disebabkan karena keterkaitan yang sangat erat dengan tujuan pemahaman agama yang dianutnya. Dengan kata lain bahasa Arab merupakan bahasa Islam yang telah menggantikan kepercayaan pribumi seperti dinamisme, animisme, Hindu, Budha, dll. Hal ini dibuktikan dengan adanya berbagai tradisi lokal maupun nasional yang menggunakan bahasa Arab, sejumlah besar kosa kata bahasa Indonesia berasal dari 
bahasa Arab, cara berfikir ulama Islam Indonesia berlandaskan ajaran agama Islam, dan penggunaan kata "membina" yang digunakan pada tujuan pengajaran bahasa arab sangat berperan dalam mempertahankan dan mengembangkan budaya.

b). Untuk membangun Indonesia

Pembangunan Indonesia bersifat materi dan spiritual, maka pengisian dan pemantapannya berdasarkan nilai-nilai agama. Selain itu Pancasila sebagai dasar negara Indonesia pada sila pertama meliputi unsur kepercayaan pada Tuhan YME, dan Islam yang dianut sebagian besar penduduk Indonesia harus menguasai bahasa Arab untuk mendalami ajarannya. Secara tidak langsung pemahaman terhadap bahasa Arab sangat penting dalam pembangunan spiritual, demi terwujudnya Indonesia yang berkarakter dan berintelektual tinggi.

\section{2). Kurikuler}

a) Agar para siswa dapat memahami al-Qur'an, al Hadits dan buku-buku yang menggunakan bahasa Arab

b) Bahasa Arab sebagai alat komunikasi

c) Bahasa Arab sebagai alat pembantu keahlian lain (Supplementary) yang dapat menopang keilmuannya, seperti dosen PBA, PAI, Syari'ah, Ushuluddin dan Dakwah yang harus memahami bahasa Arab dalam mendalami mata kuliah yang akan diajarkan

d) Untuk pembinaan para ahli bahasa arab, tidak hanya memahami materi yang berkaitan dengan bahasa Arab tetapi juga cara mengajarkannya (strategi, metode, media pembelajaran bahasa Arab, d1l).

e) Bahasa Arab sebagai alat bantu teknik (Vocational), tujuan ini dimaksudkan sebagai alat bantu pekerjaan yang bersifat 
teknis, seperti pengajaran bahasa Arab untuk keperluan pramugara dan pramugari haji.

\section{b. Tujuan Khusus (Instruksional Objectives)}

Yang dimaksud dengan tujuan khusus di sini adalah tujuan-tujuan pada masing-masing langkah/judul-judul pelajaran pada jam tertentu. Untuk merincikan tujuan ini harus beriringan dengan tujuan kurikuler yang dijabarkan pada kurikulum. Mengingat kurikulum pendidikan bahasa Arab masih memerlukan perubahan dan penyempurnaan, maka tujuan khusus ini akan lebih jelas bila diklasifikasikan terlebih dahulu, dibedakan antara tingkat dasar, menengah, lanjutan dan perguruan tinggi, dan dibedakan antara pesantren dan yang bukan pesantren. Ada beberapa hal yang harus diperhatikan dalam pengklasifikasian ini, yaitu: ${ }^{7}$

1). Dilihat dari segi jenjang dan tingkatan
a). Tingkat dasar
c). Tingkat lanjutan
b). Tingkat menengah
d). Tingkat perguruan tinggi

2). Dilihat dari segi kapasitas peserta didik yang dijabarkan secara kurikuler
a). Keahlian (Professional)
b). Alat bantu keahlian lain (Supplementer)
c). Alat bantu pekerjaan teknis (Vocational)
d). Alat komunikasi

3). Dilihat dari segi fitrah bahasa yang terdiri dari:

a) Dzat/substansi, yaitu benda kongkrit yaang diberi nama atau diberi arti dengan lafaz tertentu.

7 Bahrum Rangkuti, Pedoman Pengajaran Bahasa Arab pada Perguruan Tinggi, h. 121. 
b) Bentuk, yaitu bentuk bunyi, kata dan kalimat yang menunjukkan klasifikasi fikiran dan benda-benda serta perbuatan tertentu.

c) Isi, yaitu proses pembentukan perumusan isi benda yang nyata menjadi isi bahasa atau secara populer disebut arti.

d) Pengutaraan bahasa yang disusun dari hubungan bunyi menjadi kata dan hubungan, kata-kata menjadi kalimat sederhana, sedang dan sulit, yang dihasilkan dari proses pengenalan dan pengutaraan.

4). Dilihat dari segi pengajaran bahasa, mencakup pembelajaran:
a) Keterampilan/kompetensi bahasa reseptif (menyimak dan membaca)
b) Keterampilan/kompetensi ekspresif (berbicara dan menulis)
c) Pengetahuan teoritis tentang bahasa Arab untuk kepentingan pengembangan dan pembinaan bahasa Arab lebih lanjut, seperti pengajaran bahasa Arab pada fakultas Adab.
d) Pengajaran bahasa untuk para pengajar dan pendidik bahasa Arab seperi Jurusan Pendidikan Bahasa Arab pada Fakultas Tarbiyah.

Cakupan materi yang berkaitan dengan keterampilan/kompetensi bahasa adalah sebagai berikut:

\section{a. Kompetensi Menyimak}

1). Menyimak bacaan Al Qur'an

2). Menyimak presentasi atau diskusi

3). Menyimak proses pembelajaran

4). Menyimak lagu, nyanyian atau qashidah

5). Menyimak berita 
6). Menyimak acara radio

7). Menyimak acara televisi dan drama

8). Menyimak kisah cerita

9). Menyimak cerita aktifitas temannya

10). Menyimak teks yang didiktekan

11). Menyimak bacaan temannya.

b. Kompetensi Berbicara

1). Memperkenalkan diri

2). Membaca al Qur'an

3). Percakapan tentang kebutuhan sehari-hari

4). Tanya jawab berbahasa Arab

5). Memperkenalkan seseorang

6). Mengungkapkan peristiwa di kehidupan sekitar

7). Menyampaikan berita

8). Menceritakan kisah sesuai gambar

9). Menceritakan kondisi cuaca yang terjadi

10). Menceritakan hobi

c. Kompetensi Membaca

1). Membaca identitas diri

2). Membaca al Qur'an

3). Membaca cerita bergambar

4). Membaca petunjuk-petunjuk umum

5). Membaca materi pelajaran

6). Membaca topik inti dari koran atau majalah

7). Membaca teks yang ada di televisi

8). Membaca cerita pendek yang menarik 
9). Membaca alamat

10). Membaca bilangan

d. Kompetensi Menulis

1). Menulis kata yang didiktekan

2). Menulis teks ceramah

3). Menulis karangan

4). Menulis urutan kejadian

5). Menjawab pertanyaan

6). Meringkas materi pelajaran

7). Menulis pengumuman

8). Menulis cerita bergambar

Berikut ini penulis akan mencontohkan tujuan instruksional pembelajaran bahasa Arab pada tingkat menengah:

\begin{tabular}{|c|c|c|}
\hline No & Tujuan Kurikuler/Umum & Tujuan Instruksional/Khusus \\
\hline 1 & $\begin{array}{l}\text { Kompetensi Menyimak } \\
\text { (Para siswa dapat } \\
\text { memahami ucapan sehari- } \\
\text { hari) }\end{array}$ & $\begin{array}{l}\text { - Dengan pembelajaran kompetensi bahasa } \\
\text { secara reseptif akan membantu siswa } \\
\text { menggunakan bahasa Arab secara ekspresif } \\
\text { - Menambah pengetahuan siswa tentang } \\
\text { penggunan struktur kalimat dan pengucapan } \\
\text { yang benar sesuai makharijul huruf bahasa } \\
\text { Arab } \\
\text { - Siswa dapat menjawab dengan tepat } \\
\text { pertanyaan dengan" na'am" atau" la" } \\
\text { mengenai isi teks yang dibacakan } \\
\text { - Siswa dapat melakukan pekerjaan yang } \\
\text { diperintahkan kepada mereka (kata kerja } \\
\text { sederhana) }\end{array}$ \\
\hline
\end{tabular}




\begin{tabular}{|c|c|c|}
\hline & & $\begin{array}{l}\text { - Siswa mampu membedakan kata-kata yang } \\
\text { mempunyai kemiripan bunyi. }\end{array}$ \\
\hline 2 & $\begin{array}{l}\text { Kompetensi Berbicara } \\
\text { (Siswa mampu } \\
\text { berkomunikasi bahasa } \\
\text { Arab yang sederhana } \\
\text { secara lisan) }\end{array}$ & $\begin{array}{l}\text { - Siswa dapat memberikan informasi } \\
\text { sederhana secara sederhana } \\
\text { - Siswa dapat menjawab pertanyaan yang } \\
\text { diberikan } \\
\text { - Siswa mampu mengungkapkan pertanyaan } \\
\text { yang sesuai dengan maksud } \\
\text { - Siswa dapat melakukan sapaan bahasa Arab } \\
\text { sesuai dengan situasi } \\
\text { - Siswa mampu melakukan komunikasi secara } \\
\text { lisan sesuai dengan bidang ilmunya. }\end{array}$ \\
\hline 3 & $\begin{array}{l}\text { Kompetensi membaca } \\
\text { (Siswa dapat membaca } \\
\text { dan memahami isi teks } \\
\text { bacaan) }\end{array}$ & $\begin{array}{l}\text { - Siswa dapat membaca kalimat bahasa Arab } \\
\text { dengan lafazh dan intonasi yang benar. } \\
\text { - Siswa mampu membaca dalam hati dan } \\
\text { memahami isi bacaan. } \\
\text { - Siswa dapat menjawab pertanyaan yang } \\
\text { berkaitan dengan isi bacaan/ } \\
\text { - Siswa dapat menjelaskan kembali isi bacaaan } \\
\text { baik berupa informatif, cerita, argumentatif, } \\
\text { normatif, dll. } \\
\text { - Siswa benar-benar memahami makna yang } \\
\text { tersirat dalam isi bacaan. } \\
\text { - Siswa mampu menggunakan kamus/ } \\
\text { ensiklopedi dengan baik. }\end{array}$ \\
\hline 4 & $\begin{array}{l}\text { Kompetensi Menulis } \\
\text { (Siswa mampu } \\
\text { berkomunikasi } \\
\text { secara tertulis dengan } \\
\text { menggunakan bahasa } \\
\text { Arab) }\end{array}$ & $\begin{array}{l}\text { - Siswa dapat menulis huruf hijaiyyah yang } \\
\text { bersambung sesuai dengan perubahan } \\
\text { bentuknya. } \\
\text { - Siswa mampu menulis kalimat bahasa Arab } \\
\text { sesuai dengan struktur kata yang benar. } \\
\text { - Siswa dapat menempatkan tanda baca pada } \\
\text { kalimat. }\end{array}$ \\
\hline
\end{tabular}




\begin{tabular}{|l|l|}
\hline - Siswa mampu menyusun kata-kata acak \\
menjadi kalimat yang sempurna \\
- Siswa mampu menyusun kalimat-kalimat \\
acak menjadi paragraf yang sempurna \\
- Siswa dapat menulis karangan sederhana \\
- Siswa dapat menulis surat sederhana
\end{tabular}

\section{Relevansi Kurikulum dan Tujuan Pembelajaran}

Kurikulum berperan sebagai input instrumental sebagai sarana terwujudnya proses kegiatan pendidikan atau sebagai sarana dalam mencapai tujuan pendidikan. Oleh karena itu penyusunan kurikulum terutama dalam penentuan isi bahan pengajaran harus berdasarkan tujuan yang telah ditetapkan. Dengan demikian terjadi keselarasan antara kurikulum dan tujuan pendidikan sehingga tanggung jawab sekolah dapat dilaksanakan.

Kurikulum dapat dipandang sebagai suatu proses, yang mencakup semua kegiatan belajar mengajar dalam rangka mencapai tujuan pendidikan. Dengan demikian kurikulum bersifat normatif karena kurikulum itu sendiri harus relevan dengan tujuan pendidikan, dan tujuan pendidikan itu sendiri bergantung pada sistem nilai (pancasila). Di samping itu kurikulum juga harus peka terhadap kebutuhan dan perkembangan masyarakat. Kurikulum harus senantiasa ditinjau kembali dan dalam jangka waktu tertentu diadakan perubahan sesuai dengan perkembangan.

Kurikulum merupakan pedoman untuk melaksanakan program pengajaran. Pengajaran itu sendiri terdiri atas komponen-komponen alat pendidikan, anak didik, guru, dan situasi pendidikan yang dijalankan secara sadar dalam mencapai tujuan instruksional. Siswa dan guru adalah subjek pengajaran yang secara sadar direncanakan 
dan dilibatkan pada situasi pendidikan. Situasi ini berupa keteladanan, kedisiplinan, semangat, kegairan belajar-mengajar, ketertiban dan kebersihan sekolah, suasana yang nyaman, dan lain-lain.

Tujuan-tujuan kegiatan belajar mengajar yang langsung dapat dicapai dalam setiap berakhirnya kegiatan adalah tujuan instruksional (khusus) yang dijabarkan dari tujuan kurikuler. Namun tujuan ini belum cukup menjadikan peserta didik manusia seutuhnya, tujuan ini memerlukan tujuan pembentukan sebagai pengikat tujuan instruksional. Pencapaian kedua tujuan itu secara sekaligus akan lebih mempermudah pencapaian jenjang tujuan-tujuan yang lebih tinggi, yaitu tujuan kurikuler, institusional, dan tujuan pendidikan nasional.

Dari uraian di atas jelaslah bagi kita bahwa kurikulum merupakan sarana pencapaian tujuan-tujuan pendidikan. Seluruh unsur dan komponen yang ada di dalam kurikulum harus relevan dan menuju satu titik fokus yaitu tujuan pendidikan. Pendidikan yang berkaitan erat dengan belajar adalah usaha sadar dan sengaja dilakukan, kesadaran dan kesengajaan ini mengarah kepada perencanaan dan perumusan langkah-langkah yang akan ditempuh dalam kegiatan pendidikan. Kegiatan yang dilakukan secara sadar dan sengaja tidak mungkin terjadi jika bukan untuk mencapai suatu maksud dan tujuan. Tujuan inilah sebagai sasaran dari pendidikan yang dilakukan melalui proses dan tahapan-tahapan yang berjenjang. Semua usaha ini terangkum dalam kurikulum.

\section{Simpulan}

Kurikulum merupakan seperangkat rencana pengajaran yang didesain untuk mencapai tujuan pembelajaran. Kurikulum adalah suatu rencana atau intention yang tidak hanya berupa perencanaan (mental) saja, tetapi pada umumnya diwujudkan dalam bentuk tulisan. Kurikulum 
bukanlah kegiatan, melainkan perencanaan atau rancangan kegiatan. Kurikulum berisi berbagai macam hal seperti masalah yang harus dikembangkan dalam diri siswa, evaluasi untuk menafsirkan hasil belajar, bahan dan peralatan yang dipergunakan, kualitas guru yang dituntut, dan sebagainya. Kurikulum melibatkan maksud atau tujuan pendidikan formal, maka ia sengaja mempromosikan belajar, bukan tanpa rencana atau kegiatan tanpa belajar. Sebagai perangkat organisasi pendidikan, kurikulum menyatukan berbagai komponen seperti tujuan, isi, sistem penilaian dalam satu kesatuan yang tak terpisahkan, dengan kata lain kurikulum adalah sebuah sistem. Kurikulum harus relevan dengan tujuan pendidikan yang hendak dicapai karena kurikulum merupakan sarana pencapaian tujuan-tujuan pendidikan. Begitu juga dengan pendidikan bahasa Arab, selain menjadikan bahasa Arab seagai objek kajiannya juga mempelajari bagaimana cara mengajarkannya. Tujuan ini akan lebih mudah terwujud jika seluruh komponen kurikulum pendidikan bahasa Arab bersatu dan relevan dengan tujuan tersebut.

\section{DAFTAR PUSTAKA}

Al-Khasyat, Muhammad Utsman. Fannu Kitabah al-buhutsah al-'Ilmiyyah wa I'dat ar-Rasail al-Jami'iyyah. Kairo:Dar an-Nashr. 1876

Arsyad, Azhar. Madkhal ila Thuruq Ta'lim al Lughah al 'Ajnabiyyah. Mesir: Maktabah An Nahdhah Al Mishriyyah. 1999

As-Saman, Mahmud Ali. At-Taujih fi Tadris al-Lughah al-'Arabiyyah. Kairo: Dar al-Ma'arif, 1982

Fachrurrozi, Aziz \& Erta Mahyuddin. Teknik Pembelajaran Bahasa Arab. Bandung; CV. Pustaka Cendikia Utama. 2012

Hermawan, Acep. Metodologi Pembelajaran Bahasa Arab. Bandung: Remaja Rosdakarya. 2011 
Mudhofir, Ali. Aplikasi Pengembangan Kurikulum Tingkat Satuan Pendidikan Dan Bahan Ajar. Jakarta: Raja Grafindo Persada. 2011

M. Ahmad, Dkk. Pengembangan Kurikulum. Bandung: Pustaka Setia. 1998

Nurgiantoro, Burhan. Dasar-Dasar Pengembangan Kurukulum Sekolah. Yogyakarta: BPFE, 1988

Rangkuti, Bahrum dan Kafrawi.Pedoman Pengajaran Bahasa Arab.Jakarta: Proyek Pengembangan Sistim Pendidikan Agama Departemen Agama RI 1974

Rosyidi, Abd Wahab dan Mamlu'atul Ni'mah. Memahami Konsep Dasar Pembelajaran Bahasa Arab. Malang: UIN Maliki Press. 2012

Thu'aimah, Rusydi Ahmad. Manahuju Tadris al Lughah al 'Arabiyah bi at Ta’lim al Asasi. Kairo: Dar al Fikri al 'Arabiy. 1998

Thu'aimah, Rusydi Ahmad. Ta'lim al-Arabiyyah lighairi an-Nathiqina biha, Manahijuhu wa Asalibuhu. Rabat: Isisko. 1989

Zulhannan. Paradigma Baru Pembelajaran Bahasa Arab. Bandar Lampung: An Nur Press. 2004 